\title{
Covid-19: Trump stokes protests against social distancing measures
}

\section{Owen Dyer}

Montreal, Canada

Protests against stay at home orders, temporary business closures, and other social distancing measures imposed by US state governors have broken out in at least eight states, with the backing of President Donald Trump, who urged states to adopt those measures.

Demonstrations of a few hundred people, many of them wearing Trump merchandise and some carrying rifles and wearing body armour, have been seen over the past week in Pennsylvania, Virginia, Minnesota, Ohio, Kentucky, California, Colorado, Wisconsin, Texas, and Michigan. Others are planned in Washington state and North Carolina.

The White House published guidelines on 16 March with six recommendations for the public to follow, of which the first was: "Listen to and follow the directions of your state and local authorities." The guidelines have since been extended to the end of April.

But after protests were organised by his allies in Michigan, Minnesota, and Virginia-all Democrat run states and potential 2020 election battlegrounds-Trump sent out three tweets: "LIBERATE MICHIGAN," "LIBERATE MINNESOTA," and "LIBERATE VIRGINIA, and save your great 2nd Amendment. It is under siege!" The second amendment is the right to bear arms.

Several of the early protests were organised in Facebook groups formed by the Dorr brothers-four Minnesota far right activists who have made a living founding "no compromise" gun rights groups in several states. They founded Wisconsinites Against Excessive Quarantine last week and have since created similar groups for Pennsylvania, Ohio, and New York.

But figures in the mainstream Republican establishment have also been at work. Michigan's protest was partly funded by the powerful DeVos family, the dominant dynasty in state Republican politics. Betsy DeVos is Trump's secretary of education. Michigan has recorded 2468 covid-19 deaths, the most of any state except New York and New Jersey.

The US reported over 792000 cases and 42500 deaths to the morning of 21 April.

"Give me liberty or give me death" was a common message seen on protesters' banners. "Social distancing is communism," said one placard in California. "Covid-19 is a lie," said another. In Denver, where protesters in cars were temporarily blocked by two silent hospital workers in scrubs, a woman was filmed shouting at them: "Go to China."
One California protester's banner prefigured other arguments that may lie ahead: "Freedom isn't free if you have to have a mandated vaccine."

Protests against social distancing measures have broken out in recent days in Beirut, Baghdad, Mumbai, and the Paris suburbs. But only in the US have they had the blessing of the head of government.

Trump's stance drew criticism from Maryland's governor Larry Hogan, a Republican. "I don't think it's helpful to encourage demonstrations and encourage people to go against the president's own policy," he told CNN. "It just doesn't make any sense.

The protests come as several states are preparing to ease restrictions. These include at least three that do not meet the White House's own criteria for doing so, which require two weeks of falling numbers in several metrics. Georgia, South Carolina, and Florida all plan to relax restrictions in the coming days despite failing on at least one metric. The three states whose "liberation" Trump called for have also not met those benchmarks.

In the most conservative states, stay at home orders are not an option. David Wheeler, president of the Wyoming Medical Society, told the Washington Post of his efforts to persuade the governor to give such an order. "It's a very heavily armed population in Wyoming with a lot of uber-libertarian personalities," Wheeler said. "You can recommend people stay at home, and they'll say you can't do that, and to prove that, we're going to leave our homes. It's just a gigantic mess." Governor Mark Gordon balked at giving the order, but called Wheeler to thank him for the pressure, which "gave him additional political leverage to strongly encourage people to shelter in place," said Wheeler.

A Yahoo News and YouGov poll published 20 April found that only $22 \%$ of respondents supported the protests. ${ }^{2}$ Polls have consistently shown that people worried about restrictions easing too rapidly outnumber those worried about restrictions easing too slowly by about two to one.

White House. 15 days to slow the spread. 16 March 2020. www.whitehouse.gov/articles/ 15-days-slow-spread.

2 Romano A. Coronavirus poll: most Americans reject anti-lockdown protests. Yahoo News. 20 April 2020. news.yahoo.com/yahoo-news-you-gov-coronavirus-poll-most-americansreject-antilockdown-protests-124259347.html.

Published by the BMJ Publishing Group Limited. For permission to use (where not already granted under a licence) please go to http://group.bmj.com/group/rights-licensing/ permissions 
